\title{
ZnO-Ag core shell nanocomposite formed by green method using essential oil of wild ginger and their bactericidal and cytotoxic effects
}

\begin{abstract}
In this paper, a novel green method for fabrication of zinc oxide-silver ( $\mathrm{ZnO}-\mathrm{Ag}$ ) core-shell nanocomposite using essential oil of ginger (EO-G) is reported. The EO-G played two significant roles in the synthesis process: it could act as a reaction media for the formation of $\mathrm{ZnO}$ and reduce $\mathrm{Ag}+$ to $\mathrm{Ag} 0$. The bioformed $\mathrm{ZnO}-\mathrm{Ag}$ nanocomposite was compared with pure biosynthesized ZnO-NPs and characterized by UV-vis spectroscopy, TEM, EDX, XRD and FTIR. The characterization results confirmed that Ag-NPs had been embedded in $\mathrm{ZnO}$ hexagonal nanoparticles. Six Gram positive and negative pathogens were used to investigate the antibacterial effects of these samples. Ag-doping improves the bactericidal activity of ZnO-NPs. In vitro cytotoxicity studies on Vero cells, a dose dependent toxicity with nontoxic effect of concentration below $100 \mu \mathrm{g} / \mathrm{mL}$ was shown for $\mathrm{ZnO}-\mathrm{Ag}$ nanocomposite. The biosynthesized $\mathrm{ZnO}-\mathrm{Ag}$ nanocomposites were found to be comparable to those obtained from the conventional methods using hazardous materials which can be an excellent alternative for the synthesis of $\mathrm{ZnO}-\mathrm{Ag}$ using biomass.
\end{abstract}

Keyword: ZnO-Ag nanocomposite; Core-shell; Green synthesis; Ginger; Antimicrobial activities 